\title{
PENYUSUNAN PEDOMAN PENGELOLAAN KEUANGAN PESANTREN
}

\author{
Maskuri \\ Universitas Ibrahimy, Indonesia \\ masykuri.ismail@gmail.com
}

\begin{abstract}
Islamic boarding schools inevitably provide services for the implementation and management processes. It requires adjustments to increasing needs. Each Islamic boarding school has different characteristics, because It is founded by different figures. There are different ways to financial management in Islamic boarding schools. The role of Kiai as a central figure is very decisive in financial management. Pondok Pesantren Salafiyah Syafi'iyah Sukorejo is one of the Islamic boarding schools that have own financial management system. Three units are technically managing finances in Pondok Pesantren Salafiyah Syafi'iyah Sukorejo. They are Treasurer, the Supreme Audit and Wealth Agency of Ma'had (BPK2M), and the Budget Team. To ensure the service system in financial management, it is necessary to develop financial management guidelines. The mentoring steps taken included sharing ideas, absorbing information, discussing and conducting joint studies with stakeholders in the Islamic boarding schools. As a result, the draft financial management guidelines were included in the master plan for Islamic boarding schools. The need for guidance on financial management of Islamic boarding schools is in line with the theory of planning, innovation, and several financial regulations established by the State. In management, planning is needed because the spirit is innovation and meeting the demands of change to meet the needs of the organizers and the Islamic boarding schools community itself.
\end{abstract}

Keywords: Pengelolaan, Perencanaan, dan Inovasi Keuangan 


\section{Pendahuluan}

\section{Isu dan Fokus Pemberdayaan}

Sejak pesantren menerapkan manajemen dalam pengelolaan dan penyelenggaraan secara kombinatif, antara tradisional dan modern, pesantren telah banyak memberikan konstribusi bagi kehidupan keberagamaan, kebangsaan, kenegaraan, dan kemasyarakatan. Masingmasing konstribusi tersebut sudah dapat dirasakan manfaatnya. Secara akademik, sudah banyak penelitian yang membahas dan mengkaji pesantren Sukorejo dari berbagai aspek. Tidak jarang hasil penelitian tersebut menjadi wacana dan teori baru dalam manajemen pondok pesantren. Dalam tataran praktis, para pengelola atau umana pesantren telah mengalami kemudahan dalam menjalankan tugas dan tanggung jawabnya. Yang sangat dirasakan oleh umana' adalah ketika pesantren ini dipimpin oleh KHR. Ach. Fawaid As'ad. Meneruskan apa yang sudah menjadi tradisi dan pengelolaan pesantren yang dilakukan oleh KHR. As'ad Syamsul Arifin, Kiai Fawaid begitu tekun dan terus melakukan upaya pengembangan pesantren dengan melakukan manajemen modern berbasis pesantren salafiyah.

Setidaknya ada dua pendekatan yang dilakukan oleh Kiai Fawaid dalam menerapkan kebijakan pengelolaan pesantren, yakni mempertahankan identitas dan menawarkan ide baru sebagai inovasi penyelenggaraan pesantren. Beberapa tokoh dan pemerhati pesantren 
ada yang menyatakan, bahwa kepemimpinan Kiai Fawaid adalah periode kepemimpinan yang memadukan antara kultur dan struktur. Sebagai bukti faktual, norma-norma yang menjadi pedoman penyelenggaraan dan pengelolaan pesantren telah mengalami beberapa kali perubahan dan penyempurnaan. Perubahan itu dilakukan sebagai respon terhadap perkembangan interaksi pesantren dengan ilmu pengetahuan dan teknologi. Pedoman pesantren yang berisi beberapa ketentuan pengelolaan pesantren itu dijadikan satu dalam sebuah dokumen.

Sampai saat ini memang belum ada dokumen resmi yang menggambarkan perencanaan sebagai dasar dalam pengembangan pesantren. Beberapa ketentuan pengelolaan pesantren yang ada dalam pedoman sebagaimana dijelaskan di atas bukanlah pedoman perencanaan, tetapi lebih tepatnya pedoman pelaksanaan tugas-tugas umana. Secara the facto, setiap tahun ada proses perencanaan yang dilakukan oleh tim kecil. Seluruh unit kerja pesantren, mulai dari bidang sampai pada lembaga-lembaga unit kerja kecil menyusun perencanaan yang dituangkan dalam perencanaan anggaran. Rancangan anggaran itu sejatinya sama dengan perencanaan pada umumnya. Hanya saja, perencanaan yang dilakukan oleh masing-masing unit kerja belum mengacu pada perencanaan induk. Perencanaan dan atau 
rancangan anggaran seharusnya menggambarkan pelaksanaan visi dan misi pesantren.

Melanjutkan pendampingan mutu yang sudah dilakukan pada semester sebelumnya, pada semester tahun ini, kami memberikan pendampingan untuk menyusun pedoman pengelolaan keuangan pondok pesantren, sebagai bagian dari dokumen induk renstra. Kerja pendampingan ini nantinya akan dijadikan sebagai acuan dalam pengambilan kebijakan dan pengembangan pesantren di masa yang akan datang. Penting disadari oleh seluruh umanak dan pengelola unitunit kerja/organisasi yang ada di pesantren untuk terbiasa melakukan suatu kegiatan didasarkan pada perencanaan, sehingga dalam hal pengelolaannya tidak berdasarkan pada asumsi yang bersifat opini. Perencanaan pengelolaan keuangan yang akan dijadikan sebagai pedoman ini menjadi penting sebagai bekal bagi generasi penerus.

Dalam pengabdian masyarakat ini, ada beberapa isu dan fokus pendampingan, yaitu :

1.Belum ada dokumen yang secara khusus menjadi acuan dalam perencanaan dan pengelolaan keuangan pondok pesantren.

2.Kebutuhan manajamen sebagai pijakan dalam pengelolaan dan penyelenggaraan pesantren harus dituangkan dalam sebuah dokumen yang memuat berbagai isu strategis. 
3.Tuntutan kebutuhan masyarakat yang terus berkembang sesuai dinamika kemajuan zaman.

4.Perkembangan ilmu pengetahuan dan teknologi serta informasi yang terus berjalan begitu cepat, sebagaimana tergambarkan dalam revolusi industri 4.0.

5.Bertambahnya jumlah santri dan kebutuhan sarana prasarana yang terus bertambah setiap tahun.

6.Pengelolaan keuangan yang ada perlu dilakukan pembaruan, sebagai implementasi sunatullah dalam merespon perkembangan zaman.

\section{Tujuan}

Sebagai salah satu pengurus pada lembaga penjaminan mutu pesantren, ada proses akselerasi pencapaian mutu penyelenggaraan pesantren yang harus dikerjakan dengan penuh keseriusan. Tugas dan tanggung jawab pada LPM ini merupakan perwujudan pengabdian kepada masyarakat. Karena itu, pengabdian yang memfokuskan pada perencanaan keuangan pesantren ini memiliki beberapa tujuan sebagai berikut:

7.Terbentuknya dokumen pengelolaan keuangan sebagai acuan dalam pengembangan pesantren di masa yang akan datang.

8.Membentuk para umana' agar mempedomani pengelolaan keuangan sesuai karakteristik pesantren. 
9.Memberikan pemahaman yang sama bagi umana' dan pengelola unitunit organisasi pelaksana kebijakan pesantren agar bisa berjalan dengan tertib dan bertanggungjawab.

10.Mendorong terwujudnya tujuan-tujuan kelembagaan di lingkungan pesantren agar sejalan dengan visi dan misi pondok pesantren.

11.Membantu pengelola keuangan yang sudah ada agar ke depan berjalan sesuai dengan pedoman yang baik dan benar.

\section{Alasan Memilih Dampingan}

Lembaga penjaminan mutu pondok pesanten yang baru berdiri ini menjadi penting keberadaannya bagi proses keberlangsungan penyelenggaraan pendidikan dan pengabdian pesantren bagi pemenuhan layanan masyarakat dan tuntutan kebutuhan zaman. Pendampingan kegiatan penjaminan mutu ini memiliki signifikansi sebagai berikut:

1.Memberikan kontribusi bagi terbentuknya dokumen resmi yang akan menjadi pedoman pengelolaan keuangan di pesantren.

2.Memberikan masukan dan pertimbangan dalam proses penyusunan kerangka pedoman pengelolaan keuangan pesantren.

3.Menyatukan persepsi bagi pelaksana unit-unit organisasi dalam menjalankan tugas kepesantrenan terutama yang berkaitan dengan pengelolaan keuangan. 
4.Ikut terlibat dalam proses penyuusunan pedoman keuangan agar terbentuk lingkungan budaya mutu bagi semua pelaksana kegiatan yang ada dalam unit-unit organisasi di pesantren.

5.Para pengurus dan umana' (orang-orang yang diberi amanat) pesantren perlu secara bersama-sama terlibat dalam proses penyusunan renstra, terutama menyangkut pengelolaan keuangan. Ini dilakukan agar sejak awal seluruh umana' tahu dan mempunyai rasa memiliki (tanpa harus menjadi miliknya) terhadap keberadaan pesantren Sukorejo.

\section{Kondisi Subyek Pendampingan}

Sebagaimana digambarkan pada isu dan fokus di atas, bahwa pondok pesantren Sukorejo belum memiliki dokumen perencanaan yang menjadi rujukan seluruh unit-unit organisasi yang ada. Apa yang dikatakan sebagai dokumen selama ini merupakan dokumen yang menjadi pedoman pelaksanaan tugas dan tanggung jawab umanak yang diberi amanah oleh pesantren. Dokumen yang menjadi panduan pelaksanaan pengelolaan pesantren itu tetap mengacu pada pola kepemimpinan "sentralistik", yakni seluruh kebijakan pesantren menjadi otoritas tunggal pengasuh. Namun demikian, pengasuh tidak serta merta dalam memegang otoritas tersebut. Ada proses musyawarah, evaluasi, dan pertanggungjawaban dalam pengelolaan 
pesantren.

Sudah menjadi ketentuan umum, bahwa setiap melakukan perencanaan terlebih dahulu ada proses analisis lingkungan, baik internal maupun eksternal. Karena itu penting membuka diri dalam melihat situasi yang terus berkembang secara cepat. Ilmu pengetahuan dan teknologi begitu cepat dalam melintasi arus perubahan. Mempersiapkan diri adalah bentuk tanggung jawab dalam merespon secara nyata adanya percepatan perkembangan zaman. Menyesuaikan tidak harus larut dalam arus perubahan yang terjadi. Mempertahankan identitas sebagai basis karakter menjadi tugas dan tanggung jawab semua orang yang diberi amanat dalam mengelola pesantren.

Sampai saat ini, pesantren belum memiliki pedoman pengelolaan keuangan, sekalipun dalam praktiknya sudah melakukan fungsi manajemen keuangan. Para umanak yang terbagi dalam unit-unit kerja kelembagaan semua memiliki tanggung jawab untuk menterjemahkan visi dan misi pesantren. Gambaran pelaksanaan dalam visi dan misi tersebut diwujudkan dalam penggunaan keuangan. Kiai atau pengasuh dapat memantau perkembangan pesantren melalui pelaksanaan anggaran yang ditetapkan dalam APBM. Sejalan dengan kebutuhan manajemen, maka pesantren memerlukan suatu pedoman yang akan digunakan para umanak dalam mengelola lembaga yang dipimpinnya. 
Seperti kita maklumi, bahwa peran pesantren tidak hanya memberikan layanan penyelenggaraan pendidikan, ada peran dan fungsi dakwah dan sosial, pemberdayaan kepada umar agar menjadi pribadi mandri dalam menghadapi dinamka kehidupan. Karena itu, dalam pola kepemimpinan, pengasuh menerapkan pembagian tugas dan bahkan melimpahkan kewenangannya pada orang-orang yang diberi amanat. Untuk mencapai tujuan dan citacita pesantren dan implementasi visi dan misi, maka pesantren membutuhkan pengelolaan keuangan yang mandiri dan terencana.

Untuk menterjemahkan pengelolaan keuangan yang ada di pesantren, ada beberapa unit kerja atau unit organsisasi yang secara khusus mengelola keuangan. Sebenarnya, setiap orang yang diberi amanat di pesantren mempunyai tugas mengelola keuangan. Sehingga tanggung jawab pelaksanaan visi dan misi pesantren dapat dilihat dari bagaimana para pengurus mengelola keuangan. Unit-unit organisasi yang diberi tanggung jawab untuk mengatur jalannya keuangan pesantren adalah a) Bendahara, b) Badan Pemeriksa Kekayaan dan Keuangan Ma'had (BPK2M), dan c) Tim Anggaran Pendapatan dan Belanja Ma'had (Tim APBM).

\section{Out Put Pendampingan Yang Diharapkan}

Perencanaan suatu organisasi disusun untuk mengambil langkah- 
langkah strategis dalam rangka memenuhi target atau sasaran yang akan dicapai. Seringkali pelaksanaan kegiatan mengalami kesulitan dalam mencapai tujuan atau sasaran yang sudah ditetapkan. Kesulitan itu muncul karena adanya inkonsistensi antara perencanaan dengan pelaksanaan kegiatan. Pesantren menyusun perencanaan karena menyadari, bahwa dunia ini selalu dinamis, akan banyak berhadapan dengan perubahan yang begitu cepat, lebih-lebih dengan kecanggihan teknologi informasi yang serba digital. Tanpa perencanaan yang matang suatu organisasi bisa kehilangan arah dalam menentukan kebijakannya. Karena itu, dalam penyusunan pedoman keuangan pesantren, sebagai bagian dari perencanaan strategis ini, memiliki harapan sebagai berikut: 1.Tersusunnya pedoman keuangan pesantren sebagai acuan umum bagi setiap umanak dalam menjalankan tugas dan tanggung jawab mengelola keuangan pesantren.

2.Sebagai pedoman para umanak dalam menentukan arah kebijakan strategis dalam pelaksanaan kegiatan di pesantren;

3.Sebagai bagian dari renstra pesantren, pedoman ini memuat harapan, baik jangka pendek, menengah, maupun jangka panjang agar berjalan secara efektif dan efisien dengan kemampuan sumber daya yang dimiliki; 


\section{Metode Pendampingan Strategi yang Digunakan}

Untuk menentukan arah pelaksanaan pengabdian masyarakat dalam penyusunan pedoman keuangan pesantren, bersama tim yang memang bergabung dalam LPM menyusun strategi pelaksanaan dengan tahapan sebagai berikut:

a. Perencanaan

Dalam melaksanakan pendampingan terhadap kegiatan pengabdian kepada masyarakat, terlebih dahul saya harus membuat kerangka konseptual. Ini menjadi langkah awal sebelum melakukan kajian dan pembahasan. Konsolidasi internal untuk menyamakan persepsi menjadi penting agar pelaksanaan pendampingan dalam pengabdian masyarakat dapat berjalan dengan baik dan lancar.

b. Pelaksanaan

Kegiatan pendampingan ini dilaksanakan selama masa Oktober 2019 sampai Januari 2020 dengan tahapan sebagaimana rencana kerja dan kerangka konseptual renstra. Berdasarkan pada kerangka kerja penyusunan renstra, proses pelaksanaan penyusunan pedoman keuangan dimulai dari mengajak diskusi dengan unit-unit kerja pengelola keuangan pesantren, yaitu Bendahara, Badan Pemeriksa Keuangan dan Kekayaan Ma'had (BPK2M) dan Tim Anggaran. Dalam forum diskusi akan banyak data dan ifnormasi yang diperoleh Vo 1. $2 \mathrm{No} .2$, Oktober 2020 
oleh saya bersama tim untuk mengetahui bagaimana keuangan pesantren dikelola. Rumusan diskusi selanjutnya direduksi untuk mengidentifikasi bagian-bagian pengelolaan keuangan. Informasi itu sangat dibutuhkan untuk memberikan arah dan pembentukan persepsi yang sama bagi kelangsungan pesantren pada masa yang akan datang.

c. Evaluasi

Proses evaluasi ini secara substansi sama dengan proses penyusunan renstra. Seluruh tahapan dalam proses penyusunan renstra selalu dilakukan evaluasi. Kegiatan ini dimaksudkan agar seluruh dokumen yang akan disusun dalam renstra benar-benar konprehensif. Bentuk evaluasi itu dilakukan melalui diskusi tim, seminar, forum group discution, dan kajian terbatas bersama pengasuh pesantren Sukorejo.

d. Tindak Lanjut

Setelah diadakan evaluasi, tim renstra bersama dengan LPM merencanakan tindak lanjut sesuai catatan dan pertimbangan yang dihasilkan melalui evaluasi. Catatan diskusi yang sudah dirumuskan, selanjutnya akan dijadikan bahan pertimbangan dalam sistematika penyusunan pedoman pengelolaan keuangan pesantren. Catatancatatan penting dalam kajian dan pembahasan renstra akan menjadi 
pedoman kerja selanjutnya dalam menyempurnakan data dan informasi. Seperti yang tersebut dalam kerangka kerja atau kerangka konseptual renstra, pada bab satu akan menjadi pintu masuk bagi seluruh baba tau materi renstra.

\section{Langkah-langkah Dalam Pendampingan}

Sesuai perencanaan dan pelaksanaan kegiatan pendampingan pengabdian yang berkaitan dengan perencanaan pembentukan pedoman pengelolaan keuangan Pondok Pesantren, dapat dijelaskan beberapa langkah sebagai berikut:

Terlebih dahulu kegiatan pendampingan mengidentifikasi kondisi dan informasi penting terhadap keadaan dan situasi lingkungan Pesantren Sukorejo. Identifikasi ini bertujuan untuk mengetahui problematika pengelolaan keuangan pesantren yang akan dijadikan acuan atau pedoman bagi umanak dalam mengelola keuangan pesantren.

Setelah identifikasi dan diketahui problematika dalam pengelolaan keuangan, selanjutnya disusun tahapan kegiatan yang dikemas dalam forum diskusi kelompok sesuai dengan unit kerja yang ada di pesantren. diskusi ini dimaksudkan untuk menyerap informasi tentang berbagai hal yang berkaitan dengan manajemen pengelolaan keuangan. Tentu banyak data dan informasi yang dibutuhkan oleh tim 
pendampingan ini. Sudah diketahui, bahwa pedoman baku yang menjadi acuan dalam keseluruhan pengelolaan keuangan belum disusun. Tim mendapatkan informasi bahwa pengelolaan keuangan selama ini dipahami hanya pada unit kerja perbendaharaan, tim anggaran, dan badan pemeriksa kekayaan dan keuangan ma'had. Mereka menyampaikan bahwa rancangan pedoman keuangan pesantren sebenarnya sudah pernah disusun beberapa tahun yang lalu. Problem kesibukan yang mengakibatkan tidak focus menyebabkan rancangan pedomana keuangan pesantren tidak bisa dilanjutkan.

Untuk menggambarkan langkah pendampingan, ada beberapa tahapan yang menjadi acuan dalam pelaksanaan pendampingan, yaitu:

a. Menyusun jadwal forum group diskusi dengan unit-unit pengelola keuangan pesantren yang terdiri dari: Bendahara, BPK2M, dan Tim Anggaran;

b. Menentukan tema diskusi pendahuluan terhadap data dan informasi yang dibutuhkan selama pendampingan, seperti rancangan pedoman keuangan yang pernah dibuat, tata kerja unit pengelola keuangan, dan bentuk-bentuk rekomendasi/catatan evaluasi pelaksanaan anggaran keuangan pesantren;

c. Pendamping dilanjutkan dengan mengumpulkan data berupa dokumen yang ada di tiga unit pengelola keuangan pesantren; 
d. Verifikasi data dan identifikasi beberapa masalah pengelolaan keuangan pesantren

e. Rumusan daftar inventarisir masalah dan penyusunan kerangka keuangan pesantren agar mudah dipahami dan dapat menjadi pedoman bagi seluruh umanak.

\section{Pemilihan Subyek Dampingan}

Pelaksanaan pengabdian kepada masyarakat memilih subyek dampingan dalam hal proses penyusunan pedoman pengelolaan keuangan. Secara umum, bahwa yang dimaksudkan dengan pengelolaan keuangan adalah setiap kegiatan perencanaan, pelaksanaan, pertanggungjawaban, dan evaluasi bagi kelangsungan pengelolaan sumber keuangan pesantren. Setiap orang yang diberi tugas mengelola lembaga di pesantren pasti berhubungan dengan pengelolaan keuangan. Dalam kontek perencanaan, setiap tahun pesantren melakukannya yang diformulasikan dengan kebijakan anggaran. Untuk memastikan bahwa setiap lembaga melakukan kegiatan, maka mereka diminta membuat rencana kegiatan yang di dalamnya memuat perencanaan keuangan. Tujuan perencanaan keuangan ini untuk mengetahui para pengelola lembaga di pesantren benar-benar melaksanakan visi dan misi pesantren, sebagaimana diatur dalam pedoman pesantren. 
Ada beberapa subyek dalam pendampingan ini yang berkaitan dengan pengelolaan keuangan, sebagaimana strategi pelaksanaan di atas, yatu:

a. Pengelolaan keuangan yang dilaksanakan oleh perbendaharaan pesantren dikelola oleh bendahara dan bagian-bagian yang ada, seperti bagian evaluasi dan sinkronisasi.

b. Pengelolaan keuangan yang ada dalam wilayah perencanaan, dikelola oleh tim anggaran yang dibentuk setiap tahun.

c. Pengelolaan keuangan pesantren yang berkaitan dengan pertanggungjawaban pelaksanaan anggaran, dilaksanakan oleh Badan Pemeriksa Kekuangan dan Kekayaan Ma'had (BPK2M), dan;

d. Pengelolaan keuangan yang menjadi tanggung jawab lembaga atau unit kerja di pesantren. Untuk merealisasikan pengelolaan keuangan ini, pesantren membagi ke beberapa bidang, diantaranya bidang pendidikan, bidang pendidikan tinggi, keamanan dan ketertiban, dan lain sebagainya.

\section{Hasil dan Dampak Perubahan}

\section{Hasil Dampak Perubahan}

Dari tahapan tersebut, pendamping dapat merangkum beberapa catata proses pengelolaan keuangan yang selama ini berjalan, yaitu: 
a. Bendahara/Perbendaharaan

Lembaga atau unit organisasi pada bendahara pesantren dipimpin oleh seorang bendahara dan satu wakil bendahara. Untuk mengatur jalannya proses dan alur keuangan, tugas-tugas perbendaharaan dibantu oleh beberapa orang yang terbagi dalam bagian, sub bagian dan beberapa staf. Selama ini, tugas perbendaharaan begitu sentral, menjadi tumpuan bagi keberlangsungan seluruh kegiatan penyelenggaraan pesantren. Mengatur dan mengelola sumber pendapatan dan pembelanjaannya. Sistem ini (sentralistik) sudah berjalan beberapa tahun, bahkan dekade, terutama sejak kepemimpinan KHR. Achmad Fawad As'ad. Fakta sebenarnya bukan sentralitistik, namun pelayanan satu pintu atau satu atap. Semua penerimaan, pendapatan, dan pembelanjaan harus tercatat secara rapi, tertib, dan dapat dipertangungjawabkan.

Prinsip yang berlangsung dalam tugas-tugas perbendaharaan pesantren adalah amanah, bertanggung jawab, jujur, tertib, tepat, dan sesuai dengan ketentuan APBM. Pertanggungjawabannya disampaikan kepada pengasuh sebagai pemimpin sentral di pesantren. Dalam pengelolaan keuangan pesantren, yang menjadi rujukan adalah ketentuan keuangan yang sudah diatur dalam Anggaran Pendapatan dan Belanja Ma'had (APBM). Semua 
pengeluaran belanja dan pembiayaan kegiatan harus berdasakran pada rencana belanja yang ada dalam APBM. Perlu diketahui, bahwa APBM merupakan rencana keuangan tahunan pesantren yang digunakan sebagai standar pembiayaan seluruh kegiatan.

Kebijakan anggaran di pesantren berlaku proses perencanaan anggaran sebagaimana yang berlaku pada lembaga-lembaga pada umumnya, terdiri dari anggaran pendapatan dan belanja. Selain itu ada anggaran yang disebut dengan non budget dan budget. Yang dimaksud dengan anggaran non budget adalah anggaran yang bersumber dari pihak lain atau eksternal. Sistem pemberian honor atau gaji kepada seluruh personalia yang ada di pesantren dilakukan dengan mengacu pada ketentuan APBM. Sejak kepemimpinan KHR. Ahmad Azaim Ibrahimy, nomenklatur honor dirubah dengan sistem barokah. Ada barokah rutin sebagai pembelajaan keuangan bulanan yang prosedurnya harus dilakukan melalui beberapa tahapan. Dan bendahara akan membayarkan uang yang telah diajukan setelah memenuhi ketentuan sebagaimana yang berlaku selama ini. Masingmasing bidang mengajukan sesuai dengan tahapan bidang yang ada. Selain barokah rutin, ada juga barokah yang diberikan karena kegiatan yang sudah direncanakan. Seluruh prosedur dan 
mekanisme pengajuan barokah harus melalui tahapan yang ada dalam ketentuan APBM.

Ketentuan pemberian barokah kepanitiaan disesuaikan dengan kebijakan masing-masing bidang. Belum ada ketentuan khusus yang mengatur barokah bagi umanak yang mendapat tugas sebagai panitia, tim kerja, atau sebutan lain yang secara prinsipil memiliki kesamaan. Semua ketentuan barokah kepanitiaan dimasukkan dalam APBM.

Setiap pengajuan keuangan bagi unit-unit organisasi di pesantren harus berpedoman pada APBM. Di bendahara ada bagian evaluasi yang tugasnya melakukan verifikasi dan sinkronisasi. Kesesuaian pengajuan anggaran biaya kegiatan harus benar-benar mendasarkan pada APBM. Alurnya sangat sederhana, hanya saja bentuknya seperti draft surat yang masih harus diperbaiki, ada coretan atau catatan dari masing-masing verifikator, dan terakhir dari bagian evaluasi.

b. BPK2M

Tugas yang selama ini dilakukan adalah pemeriksaan penggunaan keuangan yang bersumber dari APBM dan ketentuan keuangan lain yang mendapat persetujuan pengasuh. Sebelum pemeriksaan, keseluruhan pelaksanaan anggaran dari sisi 
administrasi harus terlebih dahulu diverifikasi dan sinkronisasi dengan APBM.

Dalam hal pemeriksaan ke unit kerja, istilah yang digunakan adalah pendampingan melalui TURBA. Hal ini untuk menghindari kesan sebagai Lembaga yang mencari-cari kesahalan pengurus pesantren. Pendampingan yang dilakukan dalam rangka memastikan pelaksanaan anggaran agar sesuai dengan ketentuan yang ada dalam APBM.

Jika ada temuan yang terindikasi merugikan keuangan pesantren, BPK2M dapat melakukan audit investigasi dengan cara memanggil pihak-pihak yang disebutkan dalam kesimpulan sementara hasil audit untuk dimintai keterangan. Bila indikasi atau dugaan kerugian tersebut berjumlah besar, maka umanak yang bersangkutan dilaporkan kepada pengasuh untuk mendapat pembinaan dan atau sanksi.

BPK2M bersama Bendahara Pesantren melakukan sosialisasi APBM tahun berjalan kepada unit-unit organisasi yang pada biasanya diwakilkan kepada kepala TU dan bendahara unit kerja. Dalam forum sosialisasi tersebut dibuka tanya jawab, terutama pada beberapa pos anggaran yang belum dipahami. Memang diakuri bahwa belum ada format dan mekanisme pengajuan anggaran. 
c. Tim APBM

Tim APBM dibentuk setiap tahun yang bertugas menyusun perencanaan anggaran dan belanja sebagai pelaksanaan kegiatan pesantren. Yang berlangsung selama ini, tim berkedudukan tetap dalam menjalankan tugas-tugas pengelolaan keuangan pesantren. Tidak hanya menyusun anggaran, tetapi melakukan verifikasi dan sinkronisasi terhadap pelaksanaan anggaran. Sehingga terjadi tumpah tindih kewenangan dengan lembaga lain yang memiliki tugas pengelolaan keuangan, seperti bendahara dan BPK2M.

Proses Rancangan APBM dilakukan dengan melibatkan seluruh stakeholder yang ada di pesantren. Namun belum ada sistem perencanaan keuangan yang baku, maka perencanaan dilakukan dengan ketentuan sesuai dengan lembaga yang ada. Masing-masing tidak sama, sehingga dokumen utama tentang rencana keuangan tahunan masih sangat sederhana. Secara ideal perencanaan keuangan harus sejalan dengan rencana kegiatan tahunan masing-masing lembaga. Formatnya bisa menggunakan sistem Rencana Kegiatan dan Anggaran (RKA) yang dilakukan masing-masing unit kerja di pesantren.

Sesuai dengan kebutuhan dan peningkatan layanan penyelenggaraan pesantren, pedoman pesantren yang mengatur 
ketentuan pembahasan APBM sudah dilakukan perubahan. Tim APBM bukan lagi unit kerja permanen, tetapi berkedudukan sebaga unit kerja yang bersifat ad hock. Ke depan membutuhkan pedoman baku sesuai dengan pedoman pesantren yang baru.

Berdasarlan data dan informasi di atas, tentu harus memiliki dampak bagi kelangsungan penyelenggaraan pesantren, khususnya dalam hal pengelolaan keuangan. Harus ada kelanjutan yang bisa berdampak kepada perubahan bagi sistem pengelolaan keuangan yang ada di pesantren. Karena itulah, pendampingan ini memiliki dampak sebagai berikut:

1) Beberapa catatan diskusi, baik dengan unit kerja pengelola keuangan pesantren maupun dengan tim pengabdian masyarakat, akan disusun draft pedoman pengelolaan keuangan pesantren.

2) Draft sebagaimana dimaksud, akan dibahas dalam forum yang lebih luas, yaitu dengan pengurus dan umanak yang selama ini bertanggung jawab dalam menggunakan keuangan pesantren yang bersumber dari APBM.

3) Bersama dengan tim renstra, catatan dan data yang sudah terkumpul akan menjadi bahan diskusi dan seminar-seminar kecil dengan melibatkan pengurus pesantren. 
4) Bahwa pedoman pengelolaan keuangan pesantren menjadi suatu keniscayaan sebagai acuan bagi para umanak di pesantren dalam menjalankan tugas dan tanggung jawabnya.

5) Kenyataan menggambarkan, bahwa pedoman keuangan sudah lama menjadi keinginan dan kebutuhan bersama. Namun, sejalan dengan berbagai kesibukan para pengurus, pedoman keuangan nampaknya baru bisa dirumuskan kembali pada tahun 2020.

6) Para pengelola keuangan yang terbagi dalam unit-unit kerja memerlukan penyegaran dalam membangun mind site perencanaan kegiatan dan penganggaran berbasis keuangan yang baik dan benar.

\section{Diskusi Keilmuan}

Pengabdian yang dilaksanakan pada semester gasal tahun akademik 2019/2020 memfokuskan pada pendampingan penyusunan pedoman pengelolaan keuangan pesantren. Pendampingan ini merupakan kelanjutan dari pengabdian masyarakat pada semester gasal pada tahun akademik sebelumnya. Karena itu, pelaksanaan kegiatan pendampingan ini tetap bekerja sama dengan LPM Pesantren Sukorejo. Untuk memberikan gambaran akademik terhadap proses pendampingan yang saya lakukan. Pendamping perlu mendeskripsikan berbagai data sebagai bahan kajian diskusi keilmuan.

Agar data dan informasi yang diterima oleh pendamping selama 
proses pengabdian masyarakat, sangat penting mengidentifikasi beberapa temuan. Selanjutnya pendamping akan mengelaborasi dalam kajian keilmuan agar menjadi opini intelektual.

Pertama, pedoman keuangan pesantren ini menjadi instrumen penting dalam mendorong penyelenggaraan mutu pesantren. Secara teoritik, mutu diperoleh manakala adanya mental perubahan dari pelaku pengelolaan pesantren. Unit-unit organisasi yang ada di pesantren semua diarahkan pada budaya mutu dan cita-cita bersama menjadikan pesantren sebagai lembaga yang bermutu.

Kedua, unit-unit organisasi yang ada di Pesantren Sukorejo bukan hanya murni memberikan layanan pendidikan saja. Unit-unit organisasi "kecil" pesantren tersebut secara fungsional dan operasional melaksanakan kebijakan kiai/pengasuh pesantren untuk menopang tercapainya proses penyelenggaraan pesantren. Karena itulah, para pengelola pada unit-unit organisasi menjalankan tugas dan fungsinya berpedoman pada regulasi yang dibuat oleh pengasuh. Mereka semua diarahkan untuk berpikir maju dan memegang prinsip amanah dan kejuruan serta loyalitas pengabdian yang tinggi.

Dua temuan di atas menjadi perhatian pendamping untuk menjadi kajian keilmuan atau telaah akademik. Pertama temuan tentang pentingnya mutu dalam proses perencanaan dalam pengelolaan 
keuangan, dan kedua para pengelola dituntut untuk berpikir inovatif dan maju sebagai wujud nyata capaian pelayanan mutu di pesantren.

Meningkatkan mutu layanan keuangan di lembaga pesanten tidak bisa dipisahkan dengan proses layanan mutu pendidikan. Sudah menjadi opini umum, bahwa proses pendidikan dilakukan dalam rangka pengembangan sumber daya manusia. Untuk itu, dalam peningkatan mutu tersebut harus dilakukan secara terarah, terencana, dan kontinyu, sehingga mampu memasuki dunia kompetitif. ${ }^{1}$ Secara etimologis, mutu identic dengan kualitas. Dalam Kamus Bahasa Indonesia disebutkan, bahwa kualitas atau mutu itu berkaitan dengan baik buruk suatu benda, keadaan, taraf atau derajat. ${ }^{2}$ Untuk mencapai mutu layanan yang diberikan oleh pengelola keuangan, maka tidak bisa dilepaskan dari perencanaan.

Dalam proses perencanaan, ada beberapa pokok pikiran penting yang harus diperhatikan, yaitu: 1) harus berorientasi mada depan, 2) perencanaan bukan datang secara tiba-tiba, dibutuhkan proses yang matang dan cerdas, 3) para aktor perencanaan harus bertindak secara riil, bukan asumsi, dan 4) kegiatan perencanaan dilakukan secara efektif

${ }^{1}$ Barnawi, M. Arifin Sistem Penjaminan Mutu Pendidikan (Yogyakarta: Ar-Ruzz Media, 2017), 13.

${ }^{2}$ Kamus Besar Bahasa Indonesia, 1999), 677. 
dan efisien. ${ }^{3}$ Setiap langkah menuju mutu memang harus dibarengi dengan proses perencanaan yang serius, matang, dan mampu membaca lingkungan strategis, baik internal maupun eksternal. Sebagai lembaga yang berhidmat melayani ummat, yang di dalamnya ada sumbersumber keuangan, pesantren sangat memperhatikan kepastian pengelolaan keuangan. Realitas ini menjadi kenyataan yang tak terpisahkan dalam penyelenggaraan pendidikan.

Al-Qur'an juga menggariskan pentingnya perencanaan, sebagai langkah mengantisipasi apa yang akan terjadi pada masa yang datang. Disebutkan dalam firman Allah, surat al-Anfak ayat 60 :

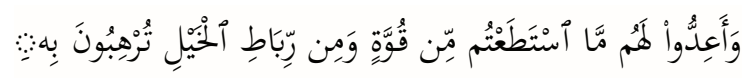

Dan disiapkanlah dengan segala kemampuan untuk menghadapi mereka dengan kekuatan yang kamu miliki dan dari pasukan kuda yang menggetarkan musuh. ${ }^{4}$ Ayat di atas sebenarnya berkaitan dengan peristiwa ketika kaum muslimin bersiap-siap menghadapi orang-orang kafir yang akan memeranginya. Untuk itu, kaum muslimin diperintahkan untuk melakukan persiapan (perencanaan) agar ketika berhadapan dengan

3 Marno dan Triyo Supriyatno, Manajemen dan Kepmimpinan Pendidikan Islam (Bandung: Refika Aditama, 2008), 14.

${ }^{4}$ Q.S.10:60, 
segala kemungkinan dalam peperangan sudah benar-benar siap. Perangkat perangkat harus dalam keadaan siap siaga, seperti kudakuda yang terlatih secara khusus.

Dinamika perkembangam zaman dan pemenuhan kebutuhan terhadap peningkatan pelayanan dalam penyelenggaraan pesantren, dianggap penting untuk memiliki suatu pedoman dan petunjuk pelaksanaan dalam mengelola asset pesantren. Tidak mudah memberikan layanan prima dalam penyelenggaraan dan pengelolaan pesantren dengan jumlah santri yang begitu besar. Benar, bahwa kiai merupakan figur sentral dalam pesantren, tetapi keberlangsungan pesantren tidak hanya dilakukan oleh seorang kiai. Dalam pandangan Sukamto, seorang kiai tidak hanya dilihat sebagai elit agama, tetapi ia menjadi elite penting di pesantren yang memiliki otoritas tertinggi. Segala kebijakannya menjadi panutan dan kiblat bagi seluruh komponen yang ada di pesantren. Apa yang dilakukan kiai akan menjadi ilmu hal bagi proses penyelenggaraan pesantren. ${ }^{5}$ Corak "sentralistik" ini sangat menentukan pola kepemimpinan pesantren yang di dalamnya ada keterkaitan dengan manajemen pengelolaan keuangan. Itulah perlunya ada manajemen dalam bagian-bagian unit kerja yang ada di pesantren.

${ }^{5}$ Sukamto, Kepemimpinan Kiai dalam Pesantren (Jakarta: LP3ES, 1999), 13-14. 
Inovasi pesantren terhadap pemenuhan kebutuhan dilakukan karena para pemimpin pesantren menyadari, bahwa perubahan itu sunatullah. Dan dengan perubahan akan membawa kepada kemajuan. Agar perubahan yang akan membawa kemajuan tidak menggerus eksistensi pesantren sebagai sub kultur, maka semua pesantren telah membentenginya dengan disiplin ilmu keagamaan dan penanaman amaliyah keagamaan yang baik dan benar. Pesantren Sukorejo sebagai salah satu dari jumlah pesantren yang ada di Indonesia, sudah banyak melakukan apa yang disebut sebagai inovasi dan pengembangan. Sampai periode kepemimpinan (pengasuh) keempat, Pesantren Sukorejo telah membuktikan inovasinya kepada masyarakat, bangsa, dan Negara. Ada inovasi fisik dan sekaligus inovasi keilmuan. Inovasi fisik bisa dilihat dari banyaknya gedung-gedung yang telah berdiri untuk memenuhi kebutuhan kenyamanan pembelajaran dan kebutuhan santri sehari-sehari. Sementara inovasi keilmuan bisa dilihat dari berbagai penghargaan akademik dan non akademik. kegiatan bahsaul masail sudah semakin progressif dengan menghasilkan keputusan yang sangat kontekstual dengan dinamika kehidupan yang sedang berkembang di tengah masyarakat.

Dikatakan sebagai lembaga pendidikan maju, menurut Nur Efendi bisa dilihat dari empat karakteristik, yaitu: 
1. Karakteristik dilihat dari konteks perubahan itu terjadi yang dipengarui oleh berbagai fator, seperti ekonomi, budaya, politik, dan sebagainya.

2. Karakteristik yang disebabkan oleh strategi pencapaian perubahan yang didukung oleh sumber daya memadai.

3. Karakteristik para pelaku perubahan dalam membangun inovasi, sejauh mana komtimen orang-orang sebagai actor perubahan mengimplementasikan inovasi sebagai basis perubahan.

4. Karakteristik dari berbagai problematika beragam inovasi itu sendiri, pemenuha kebutuhan biaya yang mencukupi, fasilitas yang memadai, bagaimana inovasi tidak menggoyah sistem yang sudah lama dibangun dan diterapkan.

Kegiatan pendampingan yang kami lakukan ini tidak bisa dipisahkan dari perspektif teoritik. Karena itu, kegiatan pengabdian kepada masyarakat melalui kerja sama dengan LPM Pesantren Sukorejo, ada beberapa teori yang dapat diwacanakan lebih jauh. Beberapa teori itu adalah 1) teori perencanaan, 2) teori kemajuan, 3) teori inovasi, dan 4) teori tentang manajemen keuang berbasis kinerja.

Secara teoritik, perencanaan (planning) merupakan arah bagi setiap proses kegiatan dalam sebuah organisasi. Karena kerja yang baik suatu lembaga atau organisasi tergantung perencanaan. Sekalipun dalam 
pelaksanaan kegiatan, organsiasi kadang tidak sejalan dengan apa yang sudah direncanakan. Namun, "penyimpangan" dari perencanaan bukan sesuatu yang akan membongkar keseluruhan dari perencanaan yang sudah ditetapkan. Made Pidarta mendefinisikan perencanaan sebagai upaya menyeleksi dan mensinergikan antar berbagai hal untuk kebutuhan masa yang akan dating. Sudah diprediksikan dalam sebuah perencanaan bahwa perubahan itu pasti terjadi, perlu diantisipasi dengan menyiapkan berbagai asumsi. Perubahan dalam kontek perencanaan dilakukan sebagai usaha inovasi organisasi agar semua yang terlibat mendapatkan kepuasan. ${ }^{6}$ Perencanaan dilakukan agar organisasi terus berdiri tegak (survive) di setiap zaman dan perkembangan keamjuan ilmu pengetahuan dan teknologi.

Dikatakan oleh Warjio, bahwa tujuan penting dalam perencanaan adalah tercapainya kesejahteraan bagi berlangsungnya kegiatan (pembagunan). Memang tidak bisa dihindarkan, bahwa proses perencanaan kadang menemukan kendala, antara seorang perencana dengan kelompok lain. Kendala ini terjadi karena persepsi yang belum menyatu. Itulah pentingnya komunikasi antar sesama perencana dan pelaksana kebijakan (dalam proses penganggaran). ${ }^{7}$ Sifat lingkungan

${ }^{6}$ Made Pidarta, Perencanaan Pendidikan Partisipatori dengan Pendekatan Sistem (Jakarta: Rineka Cipta, 2015), 2.

7 Warjio, Politik Pembangunan; Paradoks, Teori, Aktor, dan Ideologi (Jakarta: Vol. 2 No. 2, Oktober 2020 Maskuri | 308 gurnal Pengabdian Masyarakat 
yang dinamis, perubahan selalu menyertai yang dipengaruhi oleh dinamika pemikiran, situasi, globalisasi informasi, dan berbagai hal yang mengitarinya. Secara transformatif, perubahan tidak terkait dengan penambahan atau perbaikan tetapi pemindahan bentuk, bahasa, kedudukan dan sebagainya. ${ }^{8}$ Berkaitan dengan perubahan sebagai upaya inovasi, kajian postmodern memiliki andil besar dalam pengaruhnya. Wacana post-modernisme menjadi terma menarik mulai menggejala pada abad $X X$. Ada ketidakpuasan atas capaian yang telah terjadi pada masa modern. Membongkar kejumudan dan stagnasi dalam berpikir menjadi entry point dalam memasuki post-modernisme. Narasi teori yang mapan dan menjadi karakteristik arus modern mulai digugat. ${ }^{9}$

Semua orang menginginkan adanya kemajuan, namun bagaimana mencapai kemajuan membutuhkan kerja keras. Secara subyektif, kemajuan itu relatif, dikatakan maju oleh seseorang atau kelompok, belum tentu maju bagi orang lain. Sudut pandang kemajuan sangat dipengaruhi oleh sektor mana yang akan menjadi focus kemajuan. Jepang dikatakan sebagai Negara maju karena masyarakatnya disiplin

Kencana, 2016), 337.

${ }^{8}$ Wm, E. Doll, Jr., "Post Modern Curriculum”, paper (Washington DC; AERA, 1987),

9 Ali Maksum dan Luluk Yunan Ruhendi, Paradigma Pendidikan Universal di Era Modern dan Post-Modern (Yogyakarta: IRCiSoD, 2004), 93.

Vol. 2 No. 2, Oktober 2020

Maskuri | 309

Zurnal Pengabdian Masyarakat 
sehingga dapat mendorong kemajuan dibidang teknologi otomotif. Namun bagi Negara lain, kemajuan Jepan belum didukung oleh tingkat kemajuan keberagamaan pada masing-masing warga negaranya. Buktinya masih ada fenomena bunuh diri sebagai tindakan suci. Bagi masyarakat Indonesia, tindakan bunuh diri bukanlah sesuatu yang suci, tapi perilaku menyimpang, baik secara agama maupun nilai-nilaia budaya.

Wujud dari proses perubahan dan kemajuan itu antara lain lahirnya inovasi atau pengembangan. Inovasi bisa dikategorikan sebagai sesuatu yang baru atau modifikasi dari proses kreatif dari orang-orang yang memiliki sikap mental perubahan sehingga berpikir dengan kemajuan. Dengan adanya perubahan, kemajuan, dan inovasi, maka akan menghasilkan suatu capai mutu. Suatu lembaga pendidikan dikatakan bermutu apabila ada opini yang berkembang di tengah masyarakat yang telah menerima hasil dari proses penyelenggaraan pendidikan. Mutu berkaitan dengan produk yang dihasil dari proses yang disertai adanya sikap mental perubahan dan berpikir maju.

\section{Penutup}

Temuan dalam pendampingan ini akan diteruskan ke LPM sebagai bahan pertimbangan dan saran untuk menyempurnakan penyusunan pedoman pengelolaan keuangan pesantren. Keterbatasan dan kekurangan selama proses pendampingan membuat laporan Vol. $2 \mathrm{No.2,}$, $\mathrm{ktober} 2020$

Maskuri | 310 gurnal Pengabdian Masyarakat 
pengabdian kepada masyarakat perlu terus disempurnakan. Sebagai tanggung jawab akademik dan moral kepada lembaga pengelola keuangan pesantren, ada beberapa saran yang perlu disampaikan, yaitu:

a. Tim penyusunan renstra pesantren yang tergabung dalam LPM agar memperdalam pembahasannya, dengan melibatkan seluruh stakeholder yang ada di pesantren.

b. Para pengelola keuangan pesantren yang terbagi dalam beberapa unit kerja agar terus melakukan upaya perbaikan sistem pengelolaan keuangan, sehingga kebijakan anggaran yang dituangkan dalam APBM sejalan dengan garis-garis pesantren.

c. Rumusan pendampingan pengelolaan keuangan pesantren ini bisa menjadi satu dokumen penting dalam membantu menyempurnakan penyusunan pedoman pengelolaan keuangan pesantren.

\section{Daftar Pustaka}

Arifin M, Barnawi, Sistem Penjaminan Mutu Pendidikan. Yogyakarta: ArRuzz Media, 2017.

Kamus Besar Bahasa Indonesia, 1999.

Maksum Ali dan Luluk Yunan Ruhendi, Paradigma Pendidikan Universal di Era Modern dan Post-Modern. Yogyakarta: IRCiSoD, 2004.

Pidarta Made, Perencanaan Pendidikan Partisipatori dengan Pendekatan Sistem. Jakarta: Rineka Cipta, 2015.

Sukamto, Kepemimpinan Kiai dalam Pesantren. Jakarta: LP3ES, 1999.

Triyo Supriyatno Triyo, Marno, Manajemen dan Kepmimpinan Pendidikan Islam. Bandung: Refika Aditama, 2008.

Vo 1. 2 No.2, Oktober 2020 
Wm, E. Doll, Jr., "Post Modern Curriculum", paper. Washington DC; AERA, 1987. 